\title{
Prakseologiczny wymiar profilaktyki wobec zagrożeń związanych \\ z aktywnością dzieci i młodzieży \\ w cyberprzestrzeni
}

DOI: $10.47050 / 65591777.162-190$

Józef Bednarek, Adam Andrzejewski

Niniejszy artykuł dotyczy pragmatycznej orientacji działań profilaktycznych wobec zagrożeń związanych z aktywnością dzieci i młodzieży w cyberprzestrzeni. Zaprezentowano w nim najnowszą klasyfikację zagrożeń w przestrzeni wirtualnej, przeanalizowano teoretyczne podstawy zachowań problemowych w odniesieniu do zagrożeń cyberprzestrzeni, omówiono wskaźniki procesu profilaktycznego w środowisku wychowawczym dzieci i młodzieży, a także przedstawiono autorską propozycję oddziaływań rodziny i szkoły w aspekcie profilaktyki zagrożeń cyberprzestrzeni.

\section{Słowa kluczowe:}

\section{dzieci i młodzież}

cyberprzestrzeń

profilaktyka 


\section{Praxeological dimension of prevention against threats related to the activity \\ of children and young people in cyberspace}

DOI: $10.47050 / 65591777.162-190$

Józef Bednarek, Adam Andrzejewski

This publication concerns a pragmatic orientation of prevention activities, against threats related to the activity of children and youth in cyberspace. The current classification of threats in virtual space is presented. The theoretical assumptions of problem behaviors in relation to cyberspace was analyzed. The indicators of the preventive process in the educational environment of children and adolescents are discussed. The authors presented a proposal of family and school interactions in the aspect of prevention of cyberspace threats.

\section{Keywords:}

children and youth

cyberspace

prevention

threats 


\section{Wprowadzenie}

Aktywność dzieci i młodzieży w świecie zarówno realnym, jak i wirtualnym zmienia nie tylko swoje okoliczności, ale - co ważniejsze - także swój przebieg, zwłaszcza w wymiarze nowych uwarunkowań i wielorakich skutków. Stosunkowo dobrze zbadano i przedstawiono w literaturze naukowej przedmiot sygnalizowanych analiz, jego przyczyny, przebieg i konsekwencje w odniesieniu do świata realnego, również cele i zasady profilaktyki w tym względzie. Należy zwrócić uwagę, że bogaty dorobek w zakresie profilaktyki niebezpiecznych aktywności najmłodszego pokolenia w świecie rzeczywistym pozwolił na przygotowanie i stosowanie zweryfikowanych procedur w wymiarze poszczególnych zagrożeń i patologii społecznych. Z kolei zagrożenia cyberprzestrzeni nie są jeszcze w wystarczającym stopniu poddane refleksji naukowo-badawczej, przede wszystkim jednak profilaktycznej oraz terapeutycznej.

Nowe zagrożenia cyberprzestrzeni wywołały dysonans między skalą i zasięgiem patologicznych zachowań dzieci i młodzieży a obecnym stanem nie tylko profilaktyki, ale także edukacji dotyczącej bezpiecznego i odpowiedzialnego korzystania przez to pokolenie z nowych możliwości, jaką dają media i technologie cyfrowe. Ze względu na to niebezpieczne i dynamiczne zjawisko globalne (już nie tylko proces), jakże często o tragicznych skutkach, nowego wymiaru i znaczenia nabiera profilaktyka, inna od konwencjonalnych strategii działań w skali zarówno światowej, jak i lokalnej. W sytuacji nowych, wyjątkowo niebezpiecznych zagrożeń związanych z aktywnością dzieci i młodzieży w przestrzeni cyfrowej pojawia się konieczność poznania i stosowania profilaktyki o wymiarze prakseologicznym. Przedmiotem badań prakseologii jest pragmatyczna istota działania człowieka w konkretnym celu. Eksplikując naukową definicję prakseologii, warto przywołać słowa Tadeusza Kotarbińskiego: „To, co robimy, można oceniać rozmaicie, np. moralnie lub np. z punktu widzenia satysfakcji, którą sprawia uprawianie czegoś. Ale oceniać można też nie emocjonalnie, lecz utylitarnie. Chodzi wówczas o ocenę działania z punktu widzenia tak zwanych walorów technicznych: przydatności, celowości ogólniej, z punktu widzenia sprawności, która się sprowadza do dwóch głównych zalet - skuteczności i gospodarności" (Kotarbiński 1975, s. 13). Jak dalej twierdzi autor: „Tematyka jakże pociągająca dla pedagogów z dwu przynajmniej powodów. Wszak ich zadanie polega na wyrabianiu w uczniach różnych umiejętności, a przy tym ich 
własna specjalność jako pedagogów sama jest pewną umiejętnością praktyczną" (tamże, s. 22).

Ten szczególnie ważny wymiar nie jest jeszcze w pełni zbadany i zweryfikowany ze względu na stosunkowo krótki - trzydziestoletni - okres różnorodnych zastosowań internetu. Warto zwrócić uwagę, że kompetencje rodziców, nauczycieli, a także osób zajmujących się profilaktyką, są zbyt małe w obliczu dynamiki rozwoju cyberprzestrzeni i zagrożeń, jakie ona generuje.

Celem podjętych analiz jest zatem przedstawienie szerokiego i nie w pełni jeszcze zweryfikowanego prakseologicznego wymiaru profilaktyki dotyczącej dzieci i młodzieży w wymiarze wielu nowych i dynamicznie pojawiających się zagrożeń cyberprzestrzeni. Przedmiotem rozważań uczyniono następujące zagadnienia:

$\rightarrow$ teoretyczne i empiryczne uwarunkowania zagrożeń związanych z cyberprzestrzenią,

$\rightarrow$ klasyfikacja zagrożeń związanych z cyberprzestrzenią,

$\rightarrow$ teoretyczne podstawy profilaktyki zachowań problemowych,

$\rightarrow$ klasyfikacja poziomów profilaktycznych,

$\rightarrow$ klimat szkoły jako wskaźnik procesu profilaktycznego,

$\rightarrow$ styl wychowania wspierający profilaktykę,

$\rightarrow$ narzędzia kontroli rodzicielskiej aktywności dziecka online,

$\rightarrow$ scenariusz lekcji profilaktycznej w szkole.

\section{Teoretyczne i empiryczne uwarunkowania} zagrożeń związanych z cyberprzestrzenią

Poddając analizie rozwój sieci globalnej, jaką jest internet, można wskazać przynajmniej dwa czynniki, które sprawiły, że rozwiązanie to zyskało tak powszechną akceptację. Jednym z nich było urzeczywistnienie idei społeczeństwa informacyjnego i „świata bez granic”, który pozbawiony jest barier komunikacyjnych, drugim zaś - chęć stworzenia sieci komunikacyjnej, która miała służyć celom wojskowym, a która przetrwałaby nawet zniszczenie tradycyjnych środków komunikacji. Nikt się nie spodziewał, że globalna sieć przyniesie ze sobą tak ogromną liczbę możliwości. Na mapie świata, poza nielicznymi wyjątkami, nie ma już państw pozbawionych dostępu do internetu. Należy jednak pamiętać, że im głębiej wnikamy w świat cyberprzestrzeni, tym bardziej narażeni jesteśmy na różnego rodzaju zjawiska negatywne. 
"Najistotniejszymi cechami przebywania w cyberprzestrzeni są dwa podstawowe czynniki: 1) interakcyjność wysyłanych i odbieranych sygnałów; 2) teleobecność (telepresence), czy też złudzenie, polegające na wrażeniu, że jest się właśnie «tam». Aby ten efekt uzyskać, potrzebne jest tzw. kompletne zanurzenie - przynajmniej dwóch najważniejszych zmysłów, zwykle dotyczy to wzroku i dotyku" (Bednarek 2009, s. 31). Tak uzyskuje się efekt wirtualnej rzeczywistości. Proces ten bardzo szybko się rozwija i angażuje przede wszystkim młodzież i dzieci, ale w coraz większym stopniu także dorosłych. Nie ma znaczenia wykształcenie, status społeczny i to, w jakich rodzinach się funkcjonuje. Wszyscy znajdujemy się pod przemożnym wpływem najnowszych technologii informacyjnych i wirtualnej rzeczywistości, w których dominują środki, a nie cele i wartości.

Młodzi ludzie, przebywając w cyberprzestrzeni, mogą podejmować wiele aktywności, przy jednoczesnym projektowaniu i tworzeniu własnej tożsamości bez narażania się na bezpośrednią krytykę. Interaktywność cyberprzestrzeni często zastępuje kontakty z rówieśnikami i w ten sposób powstaje kategoria ludzi nazywana "elektronicznymi odludkami". Jest to młodzież bardzo dobrze radząca sobie z interakcją w wirtualnym świecie, której nie potrafi jednak nawiązać w realnym świecie. U podstaw tego rodzaju zjawiska leżą: nadpobudliwość, duża wrażliwość, niska samoocena, funkcjonowanie w rodzinie dysfunkcyjnej, trudności w radzeniu sobie z problemami życia codziennego. Zdaniem Katarzyny Krzystanek, do remisji takich zachowań prowadzą właściwe postawy rodzicielskie i dobre kontakty rodzinne, stwarzające klimat wychowawczy sprzyjający mniejszej podatności na medialną agresję (Krzystanek 2007, s. 59-68).

W tym miejscu warto przytoczyć wybrane fragmenty najnowszych badań prowadzonych przez Fundację Dajemy Dzieciom Siłę, które pokazują sposób i formy korzystania przez dzieci i młodzież z przestrzeni internetowej, a także treści, z jakimi się stykają. Analizując te badania, można dojść do wniosku, że dzieci i młodzież mają wielką swobodę w korzystaniu z zasobów cyberprzestrzeni - pod względem zarówno czasu tam spędzanego, jak i treści, z jakimi obcują.

Nastolatki korzystają z internetu dłużej w dni wolne od zajęć szkolnych. Przynajmniej trzy godziny w sieci spędza w dni powszednie $43 \%$ badanych, a kiedy nie ma lekcji, odsetek ten wzrasta do $61 \%$. Co trzeci (33\%) respondent $w$ dni wolne od zajęć korzysta $z$ internetu co najmniej 
przez pięć godzin. Co czwarty (26\%) respondent w wieku od jedenastu do osiemnastu lat przyznał, że (bardzo często lub dość często) przyłapał się na tym, że przegląda strony internetowe nawet wtedy, kiedy go to specjalnie nie interesuje. Niewiele mniej, bo $23 \%$ badanych, bez powodzenia próbowało ograniczyć czas spędzany w online, 17\% młodych ludzi czuło się nieswojo, kiedy nie mogło być w sieci, a 16\% zaniedbywało rodzinę, znajomych, naukę szkolną lub hobby z powodu spędzania czasu online. Co dwunasta osoba (8\%) ujawniła, że nie jadła lub nie spała z powodu korzystania z internetu. Połowa (51\%) dzieci korzystających z sieci przyznała, że w ciągu dwunastu miesięcy poprzedzających badanie ich rodzic lub opiekun nie zapytał o to, co robią w sieci lub jakie strony odwiedzają (Makaruk, Włodarczyk, Michalski 2017).

Istotnego wymiaru nabiera problematyka edukacji na temat właściwego, racjonalnego korzystania z cyberprzestrzeni w związku z możliwością zetknięcia się przez najmłodszych użytkowników ze szkodliwymi treściami. Niestety, jak się okazuje, tylko nieco ponad połowa (58\%) uczniów deklaruje, że w ciągu roku szkolnego poprzedzającego badanie miała w szkole zajęcia dotyczące szkodliwych treści w internecie. Najczęściej byli to najmłodsi respondenci, w wieku od jedenastu do dwunastu lat. Z kolei $65 \%$ z nich twierdzi, że nie uczestniczyło w działaniach edukacyjnych na ten temat (Makaruk, Włodarczyk, Michalski 2017).

Młodzi ludzie bardzo często stykają się z materiałami pornograficznymi i seksualizującymi. W świetle wspomnianych badań aż 43\% dzieci i nastolatków w wieku od jedenastu do osiemnastu lat miało z nimi kontakt. Z treściami o takim charakterze zetknęło się także 55\% piętnasto- i szesnastolatków oraz $63 \%$ siedemnasto- i osiemnastolatków. Co trzeci nastolatek (34\%) w wieku od piętnastu do osiemnastu lat, który zetknął się z pornografią, był tym zaniepokojony, 28\% z nich zadeklarowało, że z kimś o tym porozmawiało. Dużo rzadziej rozmawiali na ten temat $z$ innymi osobami przedstawiciele grupy siedemnasto- i osiemnastolatków - tutaj tylko $9 \%$ respondentów rozmawiało na ten temat z matką i 3\% z ojcem. Niemal dwie trzecie (61\%) badanych w wieku od jedenastu do dwunastu lat oraz $43 \%$ trzynasto- i czternastolatków, którzy zetknęli się z pornografią, było tym faktem zaniepokojone (Makaruk, Włodarczyk, Michalski 2017).

Co piąty badany (19\%), który miał kontakt z materiałami pornograficznymi, przyznał, że trafia na takie materiały codziennie, a co czwarty (24\%) - raz lub dwa razy w tygodniu. Co piąty (20\%) nastolatek w wieku 
od trzynastu do czternastu lat, który miał kontakt z pornografią, widział seks w połączeniu z przemocą. Ponad połowa (58\%) dzieci, które miały kontakt z materiałami pornograficznymi lub seksualizującymi, twierdzi, że trafiła na nie przypadkiem. Co dziesiąty respondent poszukuje jednak celowo w internecie informacji na temat seksu (Makaruk, Włodarczyk, Michalski 2017).

Jak łatwo zauważyć, cyberprzestrzeń to świat dzieci i młodzieży, w którym przebywają przez długie godziny i stykają się z różnorodnymi treściami, a także z ludźmi bardzo często zagrażającymi ich rozwojowi psychicznemu, moralnemu i społecznemu. W tym aspekcie znaczenia nabierają słowa Macieja Tanasia: „drzwi do owego świata nadal uruchamia ludzka wyobraźnia. O ile jednak w świecie mediów masowych wystarczył bierny odbiór komunikatów, o tyle w cyberprzestrzeni internauta wędruje sam, zyskuje uczucie sprawstwa, czerpiąc informacje z baz danych i rozmawiając z innymi członkami internetowej społeczności. Niestety zbyt częsta wędrówka przypomina błądzenie, a twórcza aktywność w owym świecie zastępowana jest odbiorem informacyjnych i kulturowych śmieci bądź tanią rozrywką. Bywa, że docierające [do użytkownika] treści są wynikiem ujawnianych w poszukiwaniach potrzeb i skłonności, bywa jednak i tak, że informacje trafiają [do niego] zgodnie z mniej czy bardziej kamuflowanym zmysłem nadawcy, nierzadko kalecząc umysł i serce nieświadomego dziecka, bądź pozornie tylko odpornego na medialną manipulację człowieka dorosłego" (Tanaś 2007a, s. 9).

\section{Klasyfikacja zagrożeń związanych z cyberprzestrzenią}

Obecny stan analizy literatury przedmiotu oraz badań naukowych związany ze szkodliwą i niebezpieczną funkcją komputera, internetu i jego zasobów, telefonii komórkowej oraz pozostałych technologii informacyjno-komunikacyjnych w życiu dzieci, młodzieży, dorosłych i osób starszych kieruje światło na nowe grupy konkretnych zagrożeń. Zdaniem Macieja Tanasia: „niezależnie od kierunków i sposobów analizy współczesnych technologii informacyjno-komunikacyjnych pojawia się ich wymiar społeczny i pedagogiczny. [...] Media cyfrowe stały się bowiem czynnikiem determinującym nie tylko przeobrażenia społeczne, cywilizacyjne i kulturowe, ale też (pośrednio bądź bezpośrednio) los każdego niemal człowieka, w tym co szczególnie ważne dla pedagoga - styl życia, relacje społeczne, typy aktywności poznawczej, twórczej 
a nawet ludycznej dzieci i młodzieży. W podobny sposób technologie informacyjno-komunikacyjne zmieniają też rodzaje aktywności naukowej, zawodowej, kulturowej czy społecznej osób dorosłych - choć przyznać wypada, że te przemiany nie zawsze są przez nich tak wyraźnie dostrzegane, rzadziej też oceniane pozytywnie" (Tanaś 2015, s. 11). Sylwia Galanciak podkreśla: „życie w dynamicznie przeobrażającym się świecie sprawia, że trudno dostrzec ciągłość i logikę zachodzących w nim zmian, które z perspektywy uczestnika mogą wydawać się raczej stanem radykalnego zerwania $z$ dotychczasowym porządkiem, zasługującym w pełni na miano rewolucji" (Galanciak 2015, s. 247). Warto w tym miejscu zastanowić się nad refleksją Bogusława Śliwerskiego na temat tej nowej przestrzeni w życiu człowieka, jaką jest świat wirtualny. „To, że świat wirtualny, online, często funkcjonuje jako synonim świata prawdziwego, być może nawet w pewnym stopniu wysoce przeżywanego równie prawdziwie i równie ważnie - z racji odbieranych i przekazywanych mu bodźców - to jednak prawdziwym nie jest, gdyż nie taki jest jego ontologiczny status" (Śliwerski 2016, s. 29).

W związku z tym dotychczasowe zestawienia kategorii zagrożeń wymagają bieżącej reklasyfikacji. Jest to kluczowy paradygmat dla strategii profilaktycznych. Warto zatem zaprezentować obecnie tworzoną i sukcesywnie aktualizowaną w licznych publikacjach klasyfikację zagrożeń cyberprzestrzeni autorstwa Józefa Bednarka i Anny Andrzejewskiej - pracowników naukowych Akademii Pedagogiki Specjalnej im. Marii Grzegorzewskiej:

$\rightarrow$ Zagrożenia zdrowia psychicznego i fizycznego: dolegliwości wzroku, wady słuchu, dolegliwości układu kostno-mięśniowego, dolegliwości cieśni nadgarstka, dolegliwości kciuka, schorzenia innych narządów, autodestrukcja, samookaleczenie, samobójstwa w cyberprzestrzeni, zaburzenia rozwoju psychofizycznego człowieka.

$\rightarrow$ Społeczno-wychowawcze: cyberbullying, przemoc i agresja w sieci, hazard w sieci, second life, sekty w świecie wirtualnym, handel żywym towarem i organami, zaburzenie kontaktów interpersonalnych, funkcjonowanie człowieka w świecie robotów humanoidalnych i w społeczeństwie nadzorowanym.

$\rightarrow$ Poznawczo-intelektualne: korzystanie z gadżetów elektronicznych i innych, związane z brakiem przeżywania i rozwiązywania 
problemów oraz działań w zakresie poznawania i opanowywania wiedzy.

$\rightarrow$ Zagrożenia substancjami chemicznymi: bigoreksja, uzależnienia między innymi od narkotyków, lekarstw, napojów energetyzujących, dopalaczy, suplementów diety.

$\rightarrow$ Zagrożenia moralne: cyberpornografia, prostytucja w sieci, cyberpedofilia, cyberseks, sexting, gadżety erotyczne, tatuaże, implanty, nadzorowanie i kontrola człowieka, subkultury młodzieżowe.

$\rightarrow$ Infoholizm i zagrożenia związane z grami komputerowymi (kategoria ta obejmuje przyczyny, przebieg i skutki zagrożeń oraz uzależnień).

$\rightarrow$ Zagrożenia związane z przestępczością teleinformatyczną: przestępstwa przeciwko ochronie informacji, hacking komputerowy, podsłuch komputerowy, bezprawne niszczenie informacji, sabotaż komputerowy, łamanie praw autorskich, przestępstwa przeciwko wiarygodności dokumentów, cracking, wirusy komputerowe, przechowywanie i zajęcia danych komputerowych oraz wirtualne przestępstwa finansowe (zob. między innymi: Bednarek, Andrzejewska 2018, s. 28; Andrzejewska 2018, s. 389-390).

Jak widać, zakres zagrożeń jest bardzo szeroki i w przyszłości będzie obejmować nowe, dziś jeszcze nieznane obszary. Wymienione czynniki niebezpieczne wzajemnie się dopełniają i wywołują efekt synergii w zakresie szkodliwości, co wynika z komplementarności obecnych w życiu dzieci i młodzieży urządzeń i technologii informacyjno-komunikacyjnych. Problem ten wymaga efektywnego i skutecznego przeciwdziałania. W dalszej części podjęto dyskurs na temat prakseologicznych działań profilaktyczno-wychowawczych środowiska rodzinnego i szkolnego wobec występujących zagrożeń oraz w wymiarze bezpieczeństwa dzieci i młodzieży w cyberprzestrzeni.

\section{Teoretyczne podstawy profilaktyki zachowań problemowych}

W erze czwartej rewolucji przemysłowej diagnozowane problematyczne zachowania młodzieży funkcjonującej w świecie rzeczywistym przenoszą się do cyberprzestrzeni. Dzieje się tak za sprawą wszechobecności internetu i urządzeń umożliwiających wykorzystanie technologii informacyjno-komunikacyjnych. Charakterystyczną cechą wirtualnej 
rzeczywistości stała się jej interaktywność i dynamiczność rozwoju. Zagrożenia ze świata realnego przenoszą się do świata wirtualnego. Transmisja ta działa również w przeciwnym kierunku. Aktywność w cyberprzestrzeni, inicjacja, a w następstwie długotrwały kontakt z niebezpiecznymi treściami stanowią zagrożenia dla osobistej przestrzeni psychologicznej i aksjologicznej dziecka, wyzwalają zachowania aspołeczne oraz implikują problemy osobowe i opiekuńczo-wychowawcze w świecie realnym.

\section{Koncepcja resilience - znaczenie czynników ryzyka i czynników chroniących}

Istnieją pewne procesy sprzyjające pozytywnej adaptacji człowieka w środowisku, w jakim funkcjonuje, mimo obciążenia przez różne szkodliwe, niszczące, degradujące, zagrażające i złe bodźce, określane mianem czynników ryzyka. Procesy te nie są bezpośrednio zauważalne, a o ich istnieniu możemy wnioskować na podstawie obiektywnych obserwacji życiorysów osób funkcjonujących w ciężkich warunkach bytowych. Spostrzeżenia te pozwalają postawić hipotezę, że wiele jednostek radzi sobie znacznie lepiej, niż można byłoby przewidywać na podstawie wiedzy o obciążających je czynnikach ryzyka. Wiele z nich dobrze sobie radzi również mimo obecności w ich życiu mocno stresujących doświadczeń. Przyjmuje się, że czynniki ryzyka to te, które zwiększają prawdopodobieństwo występowania niepożądanych zachowań. Okazuje się jednak, że w życiu człowieka pojawiają się również pozytywne bodźce, zabezpieczające i powstrzymujące jednostkę przed zachowaniami problemowymi - określane mianem czynników chroniących.

Konstrukcja licznych programów profilaktycznych koncentruje się na działaniach ograniczających występowanie czynników ryzyka, a tym samym zwiększania siły oddziaływania czynników chroniących (Gaś 1998, s. 9). Punktem wyjścia działań w tym kierunku jest koncepcja resilience (nazwa od angielskiego słowa oznaczającego odporność, elastyczność, adaptacyjność, sprężystość). Narodziła się ona dzięki obserwacji dzieci zagrożonych psychopatologią. Dostrzeżono, że niektóre dzieci nie ulegają negatywnym wpływom środowiska i osiągają dobre rezultaty w rozwoju, edukacji, społeczeństwie i ogólnie w życiu mimo narażenia na czynniki ryzyka. Wychowując się w niekorzystnych warunkach, rozwijają się prawidłowo i pozytywnie się adaptują. Odkrycie to zachęciło do dalszego gromadzenia wiedzy o tego rodzaju przypadkach 
i odkrywania mechanizmów regulujących oddziaływanie czynników chroniących. Poszukiwania określonych różnic u dzieci, które dobrze sobie radzą w obliczu przeciwności losu, przyczyniły się do powstania pola analiz nad profilaktyką zachowań problemowych.

Pionierką badań w dziedzinie resilience była Emmy E. Werner. Zapoczątkowane przez nią w 1955 r. trzydziestoletnie ciągłe obserwacje rozwoju grupy 698 dzieci urodzonych w tym samym roku na hawajskiej wyspie Kauai, prowadzone z zespołem złożonym z pediatrów, psychologów, psychiatrów i pracowników socjalnych, doprowadziły do wielu wartościowych konkluzji nad pozytywną adaptacją. Blisko jedna trzecia dzieci z wyspy Kauai wyrastała w bardzo trudnych warunkach (bieda, alkoholizm, problemy psychiczne rodziców, brak dostępu do edukacji). Analizując ich rozwój i indywidualne losy, badacze zaobserwowali, że mimo niesprzyjających okoliczności na wczesnych etapach rozwoju, obecności w otoczeniu potencjalnie wyniszczających czynników ryzyka, grupa ta prawidłowo się rozwijała, utrzymując po osiągnieciu dorosłości dobrostan na wyższym poziomie niż inni. Część badanych, która wykazała największą odporność, miała dostęp do sprzyjających okoliczności, elementów buforujących wobec środowiska, w jakim się wychowywała, określonych jako czynniki ochronne. Kilkudziesięcioletnie doświadczenia zespołu Emmy E. Werner skłaniają do rozważań, że chociaż wrodzone zdolności do elastyczności i sprężystości w stosunku do trudnych uwarunkowań niewątpliwie dają przewagę i pomagają, to nigdy nie jest za późno na wytworzenie czynników ochronnych, aby odeprzeć przeciwności losu (Werner, Smith 2001).

W literaturze przedmiotu można spotkać się z definicją resilience jako procesu i mechanizmów, które sprzyjają pozytywnej adaptacji w obecności dwóch komponentów: podwyższonego poziomu ryzyka w życiu jednostki oraz pozytywnej adaptacji, która jest wynikiem pokonania zagrożeń dla prawidłowego rozwoju (Borucka 2011). Koncepcja odporności, warunkująca stan dobrego funkcjonowania jednostki mimo niekorzystnych warunków życiowych, stanowi podstawę opracowywania i rozwijania programów profilaktyki zdrowia i zachowań problemowych wśród dzieci i młodzieży.

Do pionierów badań w dziedzinie resilience zaliczają się, oprócz wspomnianej Emmy E. Werner, także Michael Rutter, Norman Garmezy, Suniya Luthar, Ann Masten i Michael Ungar. Według teorii Normana Garmezy'ego wszystkie dzieci doświadczają stresu w pewnych mo- 
mentach rozwoju, żeby jednak zachować odporność, należy przejawiać "adekwatność funkcjonalną", rozumianą jako utrzymanie właściwego funkcjonowania mimo przeszkadzającej emocjonalności, stanowiącą wzorzec zachowania sprężystego w warunkach stresu (Garmezy 2011a, s. 459-466; 2011b, s. 416). Jednej z najnowszych redefinicji resilience dokonał Michael Rutter - w jego ujęciu stanowi ona interaktywną koncepcję, jaka w obrazie klinicznym jednostki wiąże się z połączeniem poważnych ryzykownych doświadczeń i stosunkowo pozytywnych wyników psychologicznych mimo tych doświadczeń (Rutter 2006, s. 1-12).

J. David Hawkins, Richard F. Catalano i Janet Y. Miller, których badania ogniskowały się w obrębie profilaktyki problemów zdrowotnych oraz behawioralnych dzieci i młodzieży, wyodrębnili listę czynników ryzyka warunkujących problematyczne zachowania adolescentów, w tym nadużywanie substancji psychoaktywnych, przestępczość, wczesną ciążę, porzucenie szkoły i przemoc. Skategoryzowali je pod względem związków z jednostką, rodziną i lokalną społecznością, zaliczając do nich między innymi dostępność do narkotyków, postawy buntownicze, przemoc w mediach, ekonomiczną deprywację potrzeb, konflikty rodzinne, brak zaangażowania w obowiązki szkolne, wczesne i uporczywe zachowania antyspołeczne, środowisko rówieśnicze angażujące w zachowania problemowe, dysfunkcjonalność rodziny (Hawkins, Catalano, Miller 1992, s. 64-105). Wyróżnili także cechy osobowe, sytuacje życiowe i warunki środowiskowe zapobiegające pojawianiu się zachowań problemowych, rozumianych jako czynniki chroniące, do których należą: silna więź emocjonalna z rodzicami, regularne praktyki religijne, szacunek dla autorytetu, pozytywny klimat szkoły, angażowanie się w aktywności prospołeczne, dobre rezultaty w edukacji (tamże, s. 64-105).

\section{Ego-resiliency jako komponent osobowości}

Resilience utożsamiana jest z typem osobowości (ego-resiliency), zdolnej do funkcjonowania w różnych sytuacjach życiowych z adekwatnym do sytuacji poziomem kontroli własnego zachowania. Osobowość ta wykazuje cechy nadające jej wyjątkową odporność w szczególnych warunkach stresu oraz utrzymywania dobrostanu mimo doświadczanych trudności (Luthar, Cicchetti, Becker 2000, s. 543-562). Pozwala to na optymalne przystosowanie społeczne, nieuleganie uzależnieniom, niewkraczanie na ścieżkę przestępczą, uzyskanie dobrych wyników 
w edukacji. W literaturze psychologicznej możemy odnaleźć wiele profili psychologicznych osób ego-resiliency.

Zainteresowanie wzbudzają wnioski badawcze Patricii J. Mrazek i Davida Mrazka, dotyczące osób, które doświadczyły ciężkiej przemocy fizycznej i psychicznej w dzieciństwie. Zaobserwowali oni pewne cechy osobowości, pozwalające tym dzieciom dobrze funkcjonować w dorosłym życiu mimo przeżytej w młodości traumy. Udaje się to osiągnąć między innymi dzięki umiejętnościom szybkiej reakcji na niebezpieczeństwo, błyskawicznego dostosowania zachowania do sytuacji, umożliwiającego uniknięcie zagrożeń, umiejętności zdystansowania się do własnych przeżyć wewnętrznych, zdolności do wyszukania i skorzystania z pomocy innych osób, poczucia odpowiedzialności za siebie, pozytywnego oczekiwania na przyszłość i pełnego optymizmu postrzegania rzeczywistości, dostrzegania w przykrych zdarzeniach konstruktywnych doświadczeń na przyszłość, podejmowania altruistycznych działań na rzecz innych ludzi (Mrazek, Mrazek 1987, s. 357-365).

Cynthia L. Jew, Kathy E. Green i Jane Kroger, konstruując skalę pomiarową resilience, ustaliły w analizie wieloczynnikowej kryteriów diagnostycznych, że odporność wyraża się w trzech dominujących właściwościach osobowościowych - optymistycznym patrzeniu w przyszłość, wierze w siebie oraz innych ludzi, przekonaniu o swoich umiejętnościach (Jew, Green, Kroger 1999, s. 75-89).

Z kolei Kathryn M. Connor i Jonathan R.T. Davidson stworzyli narzędzie pomiaru resilience na podstawie pięciu charakterystycznych zmiennych:

$\rightarrow$ kompetencji osobistych, wysokich standardów i nieustępliwości,

$\rightarrow$ wiary we własne instynkty, tolerancji negatywnego afektu,

$\rightarrow$ pozytywnej akceptacji zmian i relacji zapewniających poczucie bezpieczeństwa,

$\rightarrow$ poczucia kontroli,

$\rightarrow$ wsparcia duchowego (Connor, Davidson 2003, s. 76-82).

Synchronicznie do koncepcji resilience powstała inna teoria, za pomocą której specjaliści wyjaśniają procesy pozytywnej adaptacji i odporności w środowisku stresogennym. Należy w tym miejscu wspomnieć o teoretycznym modelu salutogenezy zaproponowanym przez Aarona Antonovsky'ego. Analizował on życiorysy osób, które przeżyły uwięzienie w obozach koncentracyjnych. U większości z nich zdiagnozowa- 
no zaburzenia psychiczne i problemy z przystosowaniem się do życia w społeczeństwie. Wyłoniła się jednak grupa, która mimo ogromnej życiowej traumy wyróżniała się dobrym zdrowiem psychicznym. W wyniku licznych studiów przypadku tych osób Aaron Antonovsky opracował koncepcję „poczucia koherencji”. Określała ją ogólna orientacja życiowa, za pomocą której można wytłumaczyć funkcjonowanie uogólnionych zasobów odpornościowych jednostki. „Poczucie koherencji” kształtuje się w wyniku zgromadzenia kompetencji indywidualnych i społecznych oraz umiejętności wykorzystywania ich w zmaganiu się z problemami oraz trudnymi, a czasami ekstremalnie stresującymi sytuacjami życiowymi. Integruje ono w sobie trzy elementy:

$\rightarrow$ zrozumiałość - świadomość napływających ze środowiska wewnętrznego i zewnętrznego bodźców o charakterze przewidywalnym i wytłumaczalnym,

$\rightarrow$ zaradność - zdolność wykorzystania dostępnych zasobów w celu skutecznego sprostania wymaganiom stawianym przez bodźce z otoczenia,

$\rightarrow$ sensowność - poczucie, że wyzwanie jest warte zaangażowania, ma wartość i sens, stanowiące pozytywną motywację jednostki do działania (Antonovsky 2005).

Organizacje międzynarodowe wykorzystują prace Aarona Antonovsky'ego w celu konstruowania i ewaluowania programów poprawy zdrowia fizycznego i psychicznego obywateli.

Poddając refleksji wszechobecność różnorodnych zagrożeń występujących w cyberprzestrzeni (takich jak dostępność do szkodliwych treści, niebezpieczne aktywności i agresywne oddziaływanie innych użytkowników), logiczne i zasadne w związku z doskonaleniem działań profilaktycznych wydaje się rozważenie adaptacji modeli opartych na koncepcji odporności wobec problemów, jakie generuje to środowisko.

\section{Klasyfikacja poziomów profilaktycznych}

Przyjmuje się, że interwencje profilaktyczne odpowiednio dostosowane do grup odbiorców i skali ryzyka zagrożeń są optymalną metodą na zahamowanie lub ograniczanie zjawisk uznawanych za dolegliwe społecznie. Eksplorując współczesne wyzwania profilaktyczne w obszarze zagrożeń związanych z cyberprzestrzenią, uwarunkowanych przez Web 2.0 i nowoczesne urządzenia technologii komputerowej, 


\section{zaadaptowano wybrane strategie działań do powszechnie przyjętej klasyfikacji poziomów profilaktyki.}

Tabela 1. Schemat interwencji w wypadku zagrożeń występujących w cyberprzestrzeni

\begin{tabular}{|c|c|c|}
\hline POZIOM & ZMIENNA & STRATEGIA INTERWENCJI \\
\hline $\begin{array}{l}\text { Profilaktyka } \\
\text { pierwszorzę- } \\
\text { dowa }\end{array}$ & $\begin{array}{l}\text { Ma charakter uniwersalny. Skierowa- } \\
\text { na do dzieci i młodzieży nieuwikła- } \\
\text { nych w problemy wynikające z aktyw- } \\
\text { ności w cyberprzestrzeni. Głównym } \\
\text { zadaniem jest funkcja informacyjna, } \\
\text { propagowanie bezpiecznego korzy- } \\
\text { stania z internetu oraz technologii } \\
\text { informacyjno-komunikacyjnych, } \\
\text { kształtowanie kompetencji medial- } \\
\text { nych, opóźnienie wieku zapoznania } \\
\text { z treściami szkodliwymi w cyberprze- } \\
\text { strzeni i tym samym zredukowanie do } \\
\text { minimum występowania zachowań } \\
\text { ryzykownych. }\end{array}$ & $\begin{array}{l}\text { Inspiracją do podejmowania działań jest rozwija- } \\
\text { nie w środowisku opiekuńczo-wychowawczym } \\
\text { wiedzy o istnieniu w cyberprzestrzeni czynników } \\
\text { zagrażających bezpiecznemu i prawidłowemu } \\
\text { rozwojowi jednostki. Pierwszymi realizatorami są } \\
\text { rodzice, którzy rozmawiają, edukują, stosują ele- } \\
\text { menty kontroli, ograniczając działanie czynników } \\
\text { ryzyka. Jednocześnie to właśnie oni wzmacniają } \\
\text { i dostarczają bodźce ochronne. } \\
\text { Program profilaktyki szkolnej w tym zakresie re- } \\
\text { alizowany jest przez specjalistów zewnętrznych, } \\
\text { pedagogów szkolnych, psychologów i nauczycieli } \\
\text { kompetentnych w tematyce cyberprzestrzeni. } \\
\text { Istotnym kierunkiem działań jest informowanie, } \\
\text { zapobieganie, rozwijanie różnych umiejętności } \\
\text { życiowych i prospołecznych wychowanków, } \\
\text { pozwalających sprostać trudom i wymogom } \\
\text { okresów rozwojowych oraz minimalizować } \\
\text { czynniki ryzyka w otoczeniu dziecka. Informacje } \\
\text { powinny być rzetelne, dostosowane do specyfiki } \\
\text { odbiorców. }\end{array}$ \\
\hline $\begin{array}{l}\text { Profilaktyka } \\
\text { drugorzę- } \\
\text { dowa }\end{array}$ & $\begin{array}{l}\text { Etap ten jest fazą wczesnej iden- } \\
\text { tyfikacji i diagnozy niewłaściwego } \\
\text { korzystania z zasobów cyber- } \\
\text { przestrzeni. Działania skupiają się } \\
\text { na wskazywaniu użytkownikom } \\
\text { objawów zaburzeń wynikających } \\
\text { z niewłaściwej aktywności w cyber- } \\
\text { przestrzeni, uświadamianiu problemu } \\
\text { oraz wsparciu w procesie wycofania } \\
\text { się z dysfunkcjonalnego korzystania } \\
\text { z zasobów cyberprzestrzeni, minima- } \\
\text { lizowaniu konsekwencji osobowych } \\
\text { i wychowawczych dzieci i młodzie- } \\
\text { ży wynikających z ich aktywności } \\
\text { w przestrzeni wirtualnej. }\end{array}$ & $\begin{array}{l}\text { Obszar interwencji obejmuje działania in- } \\
\text { formacyjne, zapobiegawcze, terapeutyczne, } \\
\text { kompensacyjne, ukierunkowane na konkretne } \\
\text { zdiagnozowane problemy wynikające z aktywno- } \\
\text { ści w cyberprzestrzeni. Podczas projektowania } \\
\text { działań należy uwzględnić specyfikę grupy od- } \\
\text { biorców wśród dzieci i młodzieży pod względem } \\
\text { występujących zaburzeń. Interwencje z reguły } \\
\text { są długotrwałe oraz wymagają aktywnej pracy } \\
\text { i zaangażowania ze strony odbiorców. Koncentru- } \\
\text { ją się na eliminacji lub redukcji czynników ryzyka, } \\
\text { jednocześnie dokładając nowe czynniki chronią- } \\
\text { ce i rozwijając siłę już występujących. Realizato- } \\
\text { rami przedsięwzięć profilaktycznych powinni być } \\
\text { specjaliści, wykwalifikowani w dziedzinie proble- } \\
\text { mów młodzieży wynikających z cyberprzestrzeni. }\end{array}$ \\
\hline
\end{tabular}




\begin{tabular}{|c|c|c|}
\hline $\begin{array}{l}\text { Profilaktyka } \\
\text { trzeciorzę- } \\
\text { dowa }\end{array}$ & $\begin{array}{l}\text { Skierowana jest do grupy wysokiego } \\
\text { ryzyka - do osób, u których wystę- } \\
\text { pują symptomy dysfunkcjonalnego } \\
\text { korzystania z zasobów cyberprze- } \\
\text { strzeni i przejawiających w wyniku } \\
\text { tego zaburzenia zachowania. Prze- } \\
\text { ciwdziała pogłębianiu się problemu } \\
\text { oraz zapobiega nawrotem zaburzeń, } \\
\text { umożliwia osobom zaburzonym } \\
\text { powrót do normalnego funkcjonowa- } \\
\text { nia oraz prowadzenia satysfakcjonu- } \\
\text { jącego i społecznie akceptowanego } \\
\text { stylu życia. }\end{array}$ & $\begin{array}{l}\text { Celem interwencji na trzecim poziomie jest wy- } \\
\text { wołanie trwałej zmiany w zachowaniu jednostki } \\
\text { oraz utrzymanie tej zmiany w jak najdłuższej } \\
\text { perspektywie czasowej. Projektując strategię } \\
\text { interwencji terapeutycznej, powinno się uwzględ- } \\
\text { niać indywidualne uwarunkowania dysfunkcji } \\
\text { jednostki w wymiarze społecznym, aktywności } \\
\text { w obszarze cyberprzestrzeni oraz specyfiki } \\
\text { zaburzeń zachowania. Działania terapeutyczne } \\
\text { cechują się dużą częstotliwością i długotrwało- } \\
\text { ścią. Intensywny charakter interwencji wymaga } \\
\text { dużego zaangażowania odbiorcy. Realizatorami } \\
\text { są specjaliści z kwalifikacjami terapeutycznymi } \\
\text { oraz klinicznymi. W niektórych przypadkach } \\
\text { wymagana jest hospitalizacja i współpraca } \\
\text { z jednostkami służby zdrowia. }\end{array}$ \\
\hline
\end{tabular}

Źródło: Opracowanie własne na podstawie: Z.B. Gaś (2006).

Analizując informacje zawarte w tabeli 1, warto zwrócić uwagę na kluczową i pragmatyczną rolę profilaktyki pierwszorzędowej. Optymalnie dostosowane i profesjonalnie wprowadzone w życie dzieci i nastolatków interwencje profilaktyczne, powiązane z edukacją opartą na rozwijaniu kompetencji medialnych, selektywnego i krytycznego odbioru zasobów medialnych cyberprzestrzeni z kształtowaniem umiejętności ich kreatywnego zastosowania, mogą zapobiec wielu patologiom. Prakseologiczny aspekt działań profilaktyki szkolnej na poziomie uniwersalnym można podsumować w następujących założeniach i celach strategicznych:

$\rightarrow$ Maksymalne podniesienie wieku inicjacji zachowań ryzykownych związanych z aktywnością w cyberprzestrzeni.

$\rightarrow$ Realizacja programów profilaktycznych w szkołach - wzbudzenie refleksji na temat przyczyn i konsekwencji podejmowanych decyzji w wirtualnym świecie, wskazanie sposobów rozwiązywania konfliktów, edukacja emocjonalna oraz wzbudzanie refleksji na temat deklarowanych i internalizowanych wartości, a także integracja grup i klas wewnątrzszkolnych.

$\rightarrow$ Upowszechnianie pozytywnych postaw i tworzenie właściwych przekonań normatywnych dzieci i młodzieży związanych z aktywnością w cyberprzestrzeni i bezpiecznym korzystaniem z jej zasobów. 
$\rightarrow$ Wsparcie w sytuacjach problemowych - zajęcia interwencyjne w klasach, doradztwo dla nauczycieli, konsultacje dla rodziców, integracja współpracy z pedagogami szkolnymi i nauczycielami.

$\rightarrow$ Usprawnianie kanałów współpracy między instytucjami, służbami, organizacjami pomocowymi, mające na celu poprawę stosowania praktyki profilaktycznej zagrożeń występujących w cyberprzestrzeni w gronie pedagogicznym.

Podsumowując, gwarancja bezpieczeństwa w zakresie korzystania przez dzieci i młodzież z możliwości oferowanych przez cyberprzestrzeń zwiększa ich szansę na zdrowy i prawidłowy rozwój fizyczny, psychiczny, psychoseksualny i społeczny. Kosztami wynikającymi z zaniechania profilaktyki pierwszorzędowej są nie tylko późniejsze obciążenia finansowe spowodowane koniecznością stosowania działań terapeutycznych, resocjalizacyjnych i rehabilitacyjnych, ale przede wszystkim krzywdzące skutki zaburzeń młodego człowieka na wielu płaszczyznach, a w skrajnych sytuacjach - utrata zdrowia i życia.

\section{Klimat szkoły wskaźnikiem procesu profilaktycznego}

Funkcjonowanie w środowisku szkolnym kształtuje doświadczenia ważne w rozwoju emocjonalnym i społecznym uczniów. Jest to niewątpliwie jeden z kluczowych obszarów powstawania tych doświadczeń w ich życiu. $\mathrm{Na}$ ich podstawie młodzi ludzie zdobywają nowe umiejętności, uczą się różnych zachowań, kształtują postawy, tożsamość i własny charakter.

Rudolf H. Moos zdefiniował "klimat szkoły” jako społeczną atmosferę środowiska edukacyjnego, wyszczególniając trzy główne sfery:

$\rightarrow$ relacje-powiązane z osobistym zaangażowaniem jednostki w ich tworzenie, poczucie przynależności oraz kolektywne udzielanie wsparcia,

$\rightarrow$ rozwój osobisty - rozumiany jako samodoskonalenie się w różnych dziedzinach osobowych i edukacyjnych przez wszystkich uczestników środowiska szkolnego,

$\rightarrow$ podtrzymywanie i doskonalenie systemu - uporządkowanie środowiska szkolnego, ustanowienie kodeksu zasad i obowiązków oraz praw wszystkich członków, wspólne zaangażowanie w przestrzeganie tych zasad (Moos 1997). 
Pozytywny, przyjazny i bezpieczny klimat szkoły umożliwia uczniom zdrowy rozwój oraz nawiązywanie i rozwijanie wzajemnych kontaktów, determinuje współdziałanie w dążeniu do określonych celów, kształtuje poczucie odpowiedzialności za nieprzestrzeganie zasad i norm.

Patrząc na kilka ubiegłych dekad, można zauważyć, że przeprowadzono na świecie wiele badań dotyczących związku klimatu szkoły z zachowaniami ryzykownymi, oddziaływaniem na zdrowie psychiczne, uzależnieniami behawioralnymi i chemicznym, występowaniem zjawiska agresji i innych patologii społecznych. Odzwierciedlenie tych samych problematycznych zachowań obserwujemy w cyberprzestrzeni, a ich etiologia jest podobna i interferuje między przyczynami w świecie rzeczywistym i wirtualnym. Agresja fizyczna przekształca się w agresję elektroniczną i mowę nienawiści. Klasyczny bullying przybiera formę cyberbullyingu. Wczesne zachowania seksualne rozpoczynają się od cyberseksu stymulowanego przez internetową pornografię. Eksperymenty związane z substancjami psychoaktywnymi przenoszą się na grunt serwisów społecznościowych, w których użytkownicy mogą bez ograniczeń wymieniać się informacjami na temat zażywania niebezpiecznych narkotyków.

W związku z istniejącym podobieństwem tych zjawisk warto poddać analizie dotychczasowe korelacje między klimatem szkoły a zachowaniami problemowymi, następnie zaś rozważyć te kwestie w powiązaniu z obecnymi i pojawiającymi się zagrożeniami oraz zaburzeniami zachowań jednostek wynikającymi ze świata wirtualnego.

Rola instytucji szkolnej w tworzeniu i podtrzymywaniu właściwego klimatu jest istotna z perspektywy profilaktyki niebezpiecznych aktywności dzieci i młodzieży w cyberprzestrzeni. W to zadanie zaangażowani powinni być nie tylko personel i kadra pedagogiczna szkoły, ale również uczniowie i rodzice. Udzielanie sobie nawzajem informacji o procesach interakcji i komunikacji w rodzinie, środowisku szkolnym, wzajemnych relacjach uczeń - uczeń oraz uczeń - nauczyciel zwiększa możliwości partycypacji w życiu szkoły i wzmacnia czynniki protekcyjne przed zagrożeniami występującymi w cyberprzestrzeni na wszystkich poziomach profilaktyki.

W 2004 r. Mona Khoury-Kassabri, Rami Benbenishty, Ron Avi Astor i Anat Zeira przeprowadzili badania w ponad 160 izraelskich szkołach. Ich wyniki wykazały, że niekorzystny klimat szkoły w znacznym stopniu zwiększał współczynnik występowania analizowanych form przemo- 
cy w szkole, obejmujących: akty ostrej agresji fizycznej, groźby przy użyciu niebezpiecznych narzędzi oraz fizyczne i psychiczne dręczenie (Khoury-Kassabri, Benbenishty, Astor, Zeira 2005, s. 187-204).

Dexter R. Voisin, Laura F. Salazar, Richard Crosby, Ralph J. Diclemente, Wiliam L. Yarber i Michelle Staples-Horne w amerykańskich badaniach na próbie 550 osób w wieku od czternastu do osiemnastu lat wykazali, że odsetek przebadanych, którzy ocenili swoich nauczycieli nisko w skali postaw i zachowań wspierających, a także zgłaszali niskie przywiązanie do nich, przejawiali dwukrotnie większą skłonność do używania substancji psychoaktywnych, do niebezpiecznych zachowań seksualnych oraz przynależności do grup przestępczych (Voisin, Salazar, Crosby, Diclemente, Yarber, Staples-Horne 2005).

Zrealizowane w 2011 r. przez Laure M. Hopson i Eunju Lee internetowe badania poprzeczne w grupie 485 uczniów pokazały, że występowanie pozytywnego klimatu (ocena jakości nauczania, wsparcia ze strony szkoły oraz jakość relacji z nauczycielami i personelem) w objętych projektem nowojorskich szkołach miało wpływ na zmniejszenie występowania zachowań problemowych, takich jak: wagary, nieodrabianie lekcji, bójki, kłótnie z nauczycielem, zawieszenie w prawach ucznia. Klimat szkoły był silniejszym czynnikiem chroniącym niż wsparcie ze strony rodziców (Hopson, Lee 2011, s. 2221-2229). Niepokojące jest to, że w świetle powyższych studiów empirycznych i analiz wielopoziomowych zaburzenia klimatu szkoły stanowią jednocześnie - według koncepcji resilience - czynniki ryzyka.

Podążając tropem rozważań Zbigniewa B. Gasia, który twierdząc, że "występujące w szkole zachowania dysfunkcjonalne uczniów (ale również dorosłych pracowników szkoły i rodziców) są najlepszym wskaźnikiem, że w środowisku szkoły konieczne są zmiany" (Gaś 2006, s. 106), uznaje, że rosnący poziom trudności wychowawczych i zaburzeń zdrowego stylu życia można regulować przez budowanie silnej, sprawnej i dobrze zintegrowanej emocjonalnie społeczności szkolnej. Istnieje związek przyczynowo-skutkowy między klimatem szkoły a występowaniem zachowań niepożądanych, które również są konsekwencją przebywania uczniów w cyberprzestrzeni.

\section{Styl wychowania wspierający profilaktykę}

Żadna instytucja społeczna nie będzie w stanie skutecznie wypełnić swojej misji profilaktycznej, jeśli będzie działać w oderwaniu od fun- 
damentalnej jednostki społecznej, jaką jest rodzina. Analizę systemowego ujęcia rodziny w polskiej literaturze psychologicznej podejmowali między innymi Jan Cz. Czabała, Mieczysław Radochoński, Maria Ryś (Czabała 1988; Radochoński 1986; Ryś 2007).

Rodzina jako pierwotne i formalne środowisko wychowawcze dziecka ma szansę stać się źródłem działań profilaktycznych, ale pod warunkiem spełnienia określonych warunków. W opinii Zbigniewa Gasia, aby było to możliwe, po pierwsze, jakość życia rodzinnego musi być konstruktywna, co należy rozumieć przez wywiązywanie się rodziny ze swoich najważniejszych funkcji. Po drugie, w rozwoju i zachowaniu dziecka nie pojawiają się zaburzenia wskazujące konieczność specjalistycznych interwencji (Gaś 2006, s. 151). Rodzina konstruktywna według koncepcji Davida H. Olsona i współpracowników to system opierający się na trzech filarach: spójności (definiowanej jako więź emocjonalna łącząca członków rodziny), adaptacyjności (rozumianej przez zdolność rodziny do reagowania na sytuacje problemowe), procesach komunikacyjnych (wzajemne porozumiewanie się członków rodziny w celu pełnienia funkcji spójności i adaptacyjności) (Olson 1991, s. 74-79; Olson 1983, s. 69-83).

Gdy rodzina nie pełni swoich funkcji, staje się dysfunkcjonalna. Według Marii Ziemskiej ten negatywny wzorzec może dotyczyć obszarów: prokreacyjnego, opiekuńczego, socjalizacyjnego, psychohigienicznego, a także niezaspokojenia potrzeb bytowych, opiekuńczych i emocjonalnych członków rodziny (Ziemska 1975, s. 35-40).

Stabilna i emocjonalnie ze sobą związana rodzina, w której dziecko jest bezpieczne i odczuwa miłość rodzicielską, jest źródłem czynników chroniących przed zagrożeniami i patologiami w świecie rzeczywistym i wirtualnym. W tabeli 2 zawarto sugestię rekomendowanych postaw wychowawczych oddziałujących na dziecko prewencyjnie przed zagrożeniami występującymi w cyberprzestrzeni. 
Tabela 2. Postawy wychowawcze kształtujące czynniki chroniące przed zagrożeniami

\begin{tabular}{|c|c|c|}
\hline POSTAWA & CECHY ZACHOWANIA & FUNKCJA PROTEKCYJNA \\
\hline $\begin{array}{l}\text { Wrażliwość } \\
\text { i empatia }\end{array}$ & $\begin{array}{l}\text { Rolą opiekuna jest wczuwanie się w stany } \\
\text { emocjonalne dziecka. Dostrzeganie } \\
\text { i właściwe interpretowanie jego nastroju, } \\
\text { ze szczególnym uwrażliwieniem na nega- } \\
\text { tywne emocje: lęk, gniew, smutek } \\
\text { czy wycofywanie się. }\end{array}$ & $\begin{array}{l}\text { Wzmocnienie więzi z rodzicami w at- } \\
\text { mosferze zrozumienia, współczucia } \\
\text { i miłości. Dziecko uczy się tworzyć relacje } \\
\text { interpersonalne oparte na empatii i za- } \\
\text { ufaniu. Kształtuje umiejętność opowia- } \\
\text { dania rodzicom o swoich problemach } \\
\text { i potrzebach oraz wczuwania się w stany } \\
\text { emocjonalne innych. }\end{array}$ \\
\hline $\begin{array}{l}\text { Wsparcie i oka- } \\
\text { zywanie atencji }\end{array}$ & $\begin{array}{l}\text { Okazywanie uwagi i zainteresowania } \\
\text { aktywnością dziecka. Otwartość do po- } \\
\text { mocy w osiąganiu jego osobistych celów } \\
\text { związanych z konsekwencjami własnych } \\
\text { wyborów. }\end{array}$ & $\begin{array}{l}\text { Kształtowanie w dziecku własnej woli } \\
\text { oraz poczucia odpowiedzialności } \\
\text { za skutki podejmowanych decyzji. }\end{array}$ \\
\hline Transparentność & $\begin{array}{l}\text { Komunikacja z dzieckiem jest zrozumiała } \\
\text { i czytelna. Zachowanie rodziców umo- } \\
\text { cowane jest w wartościach moralnych. } \\
\text { Rezygnacja z postaw cechujących się } \\
\text { labilnością i ambiwalencją. }\end{array}$ & $\begin{array}{l}\text { Modelowanie zasad i reguł właściwego } \\
\text { nawiązywania, budowania oraz utrzymy- } \\
\text { wania stosunków interpersonalnych. }\end{array}$ \\
\hline Obserwacja & $\begin{array}{l}\text { Pełna gotowość rodzica do reagowania } \\
\text { na pojawiające się sygnały alarmujące } \\
\text { o problemach dziecka. }\end{array}$ & $\begin{array}{l}\text { Wzbudzenie w dziecku poczucia bezpie- } \\
\text { czeństwa i świadomości braku osamot- } \\
\text { nienia w obliczu napotkanych trudności } \\
\text { lub niebezpieczeństw. }\end{array}$ \\
\hline Inicjacja dialogu & $\begin{array}{l}\text { Częste podejmowanie dyskusji z dziec- } \\
\text { kiem. Otwartość do rozmów na trudne } \\
\text { tematy. Aktywne słuchanie oraz respek- } \\
\text { towanie argumentów dziecka podejmo- } \\
\text { wanych w obronie jego racji. }\end{array}$ & $\begin{array}{l}\text { Nabycie przez dziecko umiejętności pro- } \\
\text { wadzenia konstruktywnego dialogu } \\
\text { oraz nauczenie go asertywności. }\end{array}$ \\
\hline Sprawiedliwość & $\begin{array}{l}\text { Adekwatne dostosowanie wymagań ro- } \\
\text { dzicielskich do fazy rozwojowej, kompe- } \\
\text { tencji, umiejętności i możliwości dziecka. }\end{array}$ & $\begin{array}{l}\text { Dziecko harmonijnie buduje własną } \\
\text { tożsamość, integrując dotychczasowe } \\
\text { doświadczenia wynikające z postaw } \\
\text { rodziców. }\end{array}$ \\
\hline Konsekwencja & $\begin{array}{l}\text { Wyznaczanie sztywnych granic w zacho- } \\
\text { waniu dziecka. Określenie reguł i zakazów. } \\
\text { Stanowcze ich egzekwowanie oraz okre- } \\
\text { ślenie konsekwencji ich nieprzestrzegania. }\end{array}$ & $\begin{array}{l}\text { Dziecko uczy się poszanowania norm, } \\
\text { zasad i reguł panujących w społeczeń- } \\
\text { stwie. Będąc świadomym negatywnych } \\
\text { konsekwencji za łamanie zasad, unika } \\
\text { zachowań ryzykownych prowadzących } \\
\text { do ich naruszenia. }\end{array}$ \\
\hline $\begin{array}{l}\text { Pełne zaangażo- } \\
\text { wanie }\end{array}$ & $\begin{array}{l}\text { Stała obecność w życiu dziecka. Towa- } \\
\text { rzyszenie mu w realizowanych zadaniach. } \\
\text { Wcielenie się w rolę przewodnika i przy- } \\
\text { jaciela. Zaoferowanie różnych kierunków } \\
\text { rozwoju, wsparcie i akceptacja w ich } \\
\text { realizacji. }\end{array}$ & $\begin{array}{l}\text { Aktywna obserwacja uczestnicząca } \\
\text { funkcjonowania dziecka w połączeniu } \\
\text { z kontrolą nad potencjalnymi czynnikami } \\
\text { ryzyka stwarza szansę na opóźnienie } \\
\text { lub całkowite niedopuszczenie do inicjacji } \\
\text { z zagrożeniami. }\end{array}$ \\
\hline
\end{tabular}

Źródło: Opracowanie własne. 


\section{Narzędzia kontroli rodzicielskiej aktywności dziecka online}

Istnieje wiele stylów wychowania. Te zbliżone do permisywnego opierają się na zaufaniu jako podstawowym argumencie za rozwojem mechanizmów samokontroli oraz wiary we własne możliwości dziecka. Z drugiej strony autokratyczne sposoby wychowania oznaczają większą kontrolę i nadzór nad aktywnością, wyborami i decyzjami wychowanka. Dzieci już od urodzenia stają się użytkownikami urządzeń cyfrowych, takich jak komputery, smartfony, tablety, a także towarzyszących im mediów. Przeprowadzone w 2014 r. amerykańskie badania dotyczące rodziców dzieci w wieku od sześciu miesięcy do czterech lat egzemplifikują niepokojący fenomen: $73 \%$ rodziców podczas wykonywania prac domowych pozwala swoim dzieciom na zabawę mobilnymi mediami, $65 \%$ uspokaja dziecko przy użyciu technologii cyfrowych, a $29 \%$ próbuje usypiać je w ten sposób (Kabali 2015).

Zjawisko to ma przełożenie na polskie realia. Badanie zrealizowane przez Fundację Dzieci Niczyje (obecnie Fundacja Dajemy Dzieciom Siłę) ujawniło, że ponad $64 \%$ dzieci w przedziale wiekowym od sześciu miesięcy do sześciu i pół roku doświadczyło inicjacji z urządzeniami mobilnymi ( $w$ tym $25 \%$ korzysta $z$ nich codziennie), 26\% ma własne urządzenie mobilne, $79 \%$ ogląda filmy, a $62 \%$ gra na smartfonie lub tablecie, $69 \%$ rodziców w momencie, kiedy zajmują się własnymi sprawami, udostępnia dzieciom urządzenia mobilne, a $49 \%$ rodziców traktuje to jako rodzaj nagrody dla dziecka (Bąk 2015, s. 7). Z kolei w badaniu z 2017 r., przeprowadzonym przez Fundację Dajemy Dzieciom Siłę na grupie 3943 respondentów w wieku od jedenastu do osiemnastu lat, prawie połowa (46\%) dzieci korzystających codziennie $z$ internetu przyznała, że w ich rodzinach nie obowiązują żadne zasady dotyczących bezpieczeństwa online. W wypadku młodzieży w wieku od siedemnastu do osiemnastu lat ten odsetek wynosi aż $76 \%$. Tylko co dziewiąta osoba (11\%) twierdziła, że jej telefon był wyposażony w program do kontroli rodzicielskiej. Rodzice co czwartego dziecka w wieku od jedenastu do czternastu lat (24\%) nie wprowadzili żadnych zasad korzystania $z$ internetu, a co trzecie dziecko (34\%) ma zakaz odwiedzania stron dla dorosłych (Makaruk, Włodarczyk, Michalski 2017).

Najmłodsi użytkownicy nie mają odpowiednich zdolności ani wystarczających umiejętności świadomego, krytycznego i selektywnego wyboru i odbioru treści w internecie, na przykład prezentujących przemoc czy pornografię. Z powodu dziecięcej naiwności i łatwowierno- 
ści pozostawione same sobie w przestrzeni sieci społecznościowych szczególnie narażone są na intencjonalne wykorzystywanie przez inne osoby. W związku z tym warto rozważyć, na skomplikowanej drodze wychowania do mediów, zastosowanie przez opiekunów elementów nadzoru aktywności najmłodszych użytkowników w internecie. Na rynku oprogramowania komputerowego oraz aplikacji komórkowych dostępnych jest wiele praktycznych i skutecznych narzędzi ułatwiającym rodzicom kontrolowanie pola aktywności dziecka w cyberprzestrzeni.

Ze względu na ograniczone ramy niniejszego artykułu zaprezentowane zostaną te, które - według autorów - zasługują na szczególną uwagę:

$\rightarrow$ Przeglądarka BeSt-bezpłatna przeglądarka stron internetowych skierowana do użytkowników w wieku od trzech do dziesięciu lat. Projekt realizowany jest przez Fundację "Dajemy Dzieciom Siłę" oraz Fundację Orange w ramach programu Komisji Europejskiej "SaferInternet". Oprogramowanie oferuje skuteczną ochronę dziecka podczas korzystania z internetu przez dostęp do ośmiu katalogu serwisów i stron bezpiecznych dla dzieci oraz funkcję blokady dostępu do stron spoza katalogu BeSt. Funkcja „Opiekun" umożliwia dodatkowo między innymi monitorowanie stron odwiedzanych przez dzieci, monitorowanie stron zablokowanych, opcjonalne ograniczenie korzystania $z$ innych programów podczas działania przeglądarki BeSt.

$\rightarrow$ Beniamin - program komputerowy umożliwiający nadzór dziecka w zakresie dostępu do różnych usług związanych z internetem. Umożliwia blokadę stron internetowych na podstawie ustawień preferowanych przez osobę kontrolującą dostęp do komputera. Dodatkowo oferuje możliwość ograniczonego dostępu do wybranych funkcjonalności (między innymi komunikatorów, list dyskusyjnych, ściągania plików z sieci, poczty e-mail, zarządzania dostępem do serwisów wideo i serwisów społecznościowych). Program jest intuicyjny w konfiguracji i bezpłatny przez czternaście dni. Po tym czasie, aby móc dalej z niego korzystać, należy wykupić licencję.

$\rightarrow$ Kurupira WebFilter - bezpłatna, łatwa w obsłudze aplikacja komputerowa oferująca szeroki wachlarz możliwości do ochrony rodzicielskiej. Umożliwia ona między innymi kontrolowanie odwiedzanych stron internetowych, uruchamianych aplikacji, a także 
nadzorowanie czasu spędzonego przez dziecko przed komputerem. Po uruchomieniu program działa w ukryciu, a dostęp do panelu jest zabezpieczony hasłem. Ponadto pozwala on blokować wybrane komunikatory internetowe i serwisy społecznościowe. Rodzice otrzymują również funkcję generowania raportów $z$ historii odwiedzanych przez dziecko stron internetowych.

$\rightarrow$ Anti-Porn Parental Controls - rozszerzenie funkcjonalności dla najpopularniejszych przeglądarek internetowych, takich jak Firefox, Internet Explorer, Chrome, Opera, Netscape i innych. Rolą aplikacji jest filtrowanie stron o tematyce pornograficznej, które są blokowane na podstawie ich opisów i zawartości multimedialnej. Dodatkową możliwością jest zaprogramowanie limitu czasu, jaki dziecko spędza przed ekranem komputera. Aplikacja jest bezpłatna i prosta w instalacji.

$\rightarrow$ Spyrix Free Keylogger - bezpłatny program komputerowy do monitorowania i rejestrowania wykonywanych czynności na komputerze. Może mieć szerokie zastosowanie do śledzenia aktywności dziecka, między innymi na portalach społecznościowych i forach dyskusyjnych, pod względem publikowanych materiałów, treści rozmów z innymi użytkownikami oraz rodzaju wyszukiwanych informacji. Program działa w ukryciu i rejestruje wszystkie naciśnięte klawisze, zapamiętując i zapisując informacje w schowku systemowym. Oferuje dodatkowo funkcję cyklicznego wykonywania zrzutów z ekranu monitora i rejestracji obrazu wideo za pomocą kamery internetowej.

$\rightarrow$ Kids Place - całkowicie darmowa aplikacja mobilna na smartfony i tablety z systemem operacyjnym Android. Umożliwia realizowanie nadzoru rodzicielskiego za pomocą telefonu komórkowego opiekuna. Pozwala na zaprojektowanie "placu zabaw” dla dziecka. Opiekun wybiera aplikacje, z których dziecko może korzystać, blokując tym samym dostęp do programów, aplikacji i funkcji, na które nie daje przyzwolenia. Narzędzie oferuje ponadto możliwości: blokowania instalowania przez dziecko gier i aplikacji, kontroli i definiowania czasu korzystania z telefonu, kontrolowania esemesów oraz połączeń wychodzących i przychodzących. Panel konfiguracyjny zabezpieczony jest kodem PIN, co uniemożliwia dziecku wyłączenie funkcji aplikacji. 
$\rightarrow$ Norton Family - aplikacja na telefony komórkowe i tablety przeznaczona dla systemów Android i iOS. Pozwala utworzyć dwa oddzielne profile: dla rodzica oraz dla dziecka. Z konta rodzica można ustawiać poziom kontroli, na przykład wybierając strony, na które dziecko może wchodzić, lub ustalając, jakich aplikacji może używać lub jakie może instalować. Dostępne są również funkcje "Alerty" i „Działania”, które pozwalają monitorować i informować opiekuna o podjętych przez dziecko aktywnościach za pośrednictwem urządzenia mobilnego oraz o tym, jakie reguły nadzoru dziecko próbowało złamać.

$\rightarrow$ Family Time - aplikacja do kontroli rodzicielskiej przeznaczona dla urządzeń mobilnych opartych na systemie operacyjnym iOS. Program oferuje szerokie możliwości w zakresie nadzoru rodzicielskiego nad korzystaniem przez dzieci z urządzeń mobilnych i internetu. W aplikacji znajduje się między innymi funkcja kontroli czasu korzystania z urządzenia przez dziecko, opcja wyłączenia możliwości korzystania z internetu w godzinach nocnych, blokada stron pornograficznych, katalog niebezpiecznych stron internetowych, usługi geolokalizacji, kontrola połączeń telefonicznych oraz esemesów.

\section{Scenariusz lekcji profilaktycznej w szkole}

Rozwiązania ustawowe zobowiązują szkoły do prowadzenia całościowych działań profilaktycznych. Niestety, nie w każdym szkolnym programie profilaktycznym znajduje się miejsce na problematykę zagrożeń związanych z cyberprzestrzenią i mediami społecznościowymi. $\mathrm{Na}$ Facebooku mogą zrejestrować się już trzynastolatkowie, przy czym w praktyce aktywne profile mają zdecydowanie młodsze dzieci. Anonimowość daje uwodzicielom, pedofilom i oprawcom kierującym się złymi intencjami w stosunku do nieletnich możliwość przyjęcia dowolnej tożsamości. W zrealizowanym przez Naukową i Akademicką Sieć Komputerową badaniu z 2016 r. spośród 1294 respondentów prawie jedna czwarta (23,1\%) nastolatków (wynik o 12,5\% wyższy niż w 2014 r.) przyznała, że zdarzyło im się spotkać bezpośrednio z dorosłym poznanym w internecie, $29 \%$ tych, którzy to zrobili, nikogo nie poinformowała 
o takim spotkaniu, tylko 39\% powiadomiło o tym rodziców 1 . Problematyka groomingu online powinna być jednym z priorytetów działań profilaktycznych w szkołach, ponieważ w zderzeniu z rzeczywistością wyrządza najwięcej zła.

Poniższy scenariusz prezentuje orientacyjny przebieg warsztatów dotyczących groomingu, skierowanych do uczniów szkoły podstawowej.

\section{Temat: Grooming - nowe zagrożenie w serwisach społecznościowych}

Czas trwania: 90 minut.

Odbiorcy: uczniowie klas IV-VI szkoły podstawowej.

Osoba prowadząca: pedagog, psycholog lub wychowawca klasy.

Cele spotkania:

$\rightarrow$ zwrócenie uwagi dzieci na zjawisko groomingu w portalach społecznościowych,

$\rightarrow$ dostarczenie podstawowych informacji na temat rozpoznania sylwetki uwodziciela w serwisach społecznościowych,

$\rightarrow$ zapoznanie uczniów z czynnikami chroniącymi oraz czynnikami ryzyka, przekazanie informacji o tym, gdzie szukać pomocy w wypadku kontaktu niebezpiecznym uwodzicielem w internecie.

Metody pracy:

$\rightarrow$ krótki wykład,

$\rightarrow$ dyskusja.

Środki dydaktyczne:

$\rightarrow$ arkusze papieru i długopisy,

$\rightarrow$ załącznik nr 1 - historia Ani.

$\rightarrow$ załącznik nr 2 - lista czynników chroniących przed groomingiem oraz wskazówki, gdzie szukać pomocy.

Raport z badań: Nastolatki 3.0. Wybrane wyniki ogólnopolskiego badania uczniów w szkołach 2016. Badania były realizowane przez zespół badawczy Naukowej i Akademickiej Sieci Komputerowej pod kierownictwem prof. dr. hab. Macieja Tanasia w składzie: Wojciech Kamieniecki, Marcin Bochenek, Agnieszka Wrońska, Rafał Lange, Mariusz Fila i Bartosz Loba. Badanie zostało przeprowadzone przez Fundację Pedagogium we współpracy z Ośrodkiem Sondaży Społecznych Opinia w czerwcu 2016 r. pod opieką naukową prof. dr. hab. Marka Konopczyńskiego. 
Przebieg spotkania:

Część wstępna:

Powitanie uczestników przez osobę prowadzącą, zapoznanie z tematem oraz omówienie zasad pracy (5 min).

Część główna:

Ćwiczenie 1. Jak rozpoznawać i chronić się przed zagrożeniem? (40 min).

Nauczyciel rozdaje uczniom historię trzynastoletniej Ani (Załącznik nr 1). Następnie dzieli klasę na trzy grupy. Grupy wybierają liderów, którzy będą prezentowali rezultaty pracy na forum klasy. Każda grupa otrzymuje kartkę do flipchartu oraz długopisy. Uczniowie w grupach zapoznają się z otrzymaną historią i pracują nad jednym zagadnieniem. Pierwsza grupa odpowiada na pytanie: „Co może uchronić Anię przed kontaktem z niebezpiecznym uwodzicielem?", druga: „W jaki sposób Ania może rozpoznać uwodziciela w serwisach społecznościowych?", trzecia: „Gdzie Ania powinna szukać pomocy, gdy spotka w internecie uwodziciela dzieci?". Przedstawiciele grup spisują pomysły na kartkach (10 min), a następnie prezentują wyniki pracy. Grupy opracowujące te same zagadnienia uzupełniają nawzajem swoje wypowiedzi (15 min). Po prezentacji nauczyciel przedstawia planszę (Załącznik nr 2) z czynnikami chroniącymi i zaznacza te, na które uczniowie zwrócili uwagę. Następnie pokazuje, jakie inne zasoby mogą im pomóc w rozwiązaniu trudnej sytuacji (15 min).

Ćwiczenie 2. Oferta pomocowa w sytuacji kontaktu z zagrożeniem (20 min).

Prowadzący, nawiązując do historyjki, pyta uczniów, do kogo Ania może zwrócić się z prośbą o pomoc. Następnie zapisuje wypowiedzi uczniów na tablicy lub flipcharcie (można podzielić pomoc na instytucjonalną i koleżeńską/osobistą). Jeżeli jest taka potrzeba, uzupełnia informacje. Na zakończenie zajęć prowadzący rozdaje uczniom wydruki z czynnikami chroniącymi oraz telefonami zaufania (Załącznik nr 2). Podsumowanie: refleksje uczniów (25 min).

Załącznik nr 1 - historia Ani

Ania ma trzynaście lat i chodzi do szóstej klasy szkoły podstawowej. Jest aktywną użytkowniczką Facebooka. Jakiś czas temu zaprosił ją do grona znajomych pewien chłopak, którego dziewczynka osobiście nie znała. Podawał się za czternastoletniego Pawła, który chodzi do tej 
samej szkoły. Przez pewien czas Ania wymieniała z nim wiadomości przez aplikację Messenger. Paweł był bardzo miły, komplementował wygląd Ani, komentował jej zdjęcia i lajkował posty. Pewnego dnia poprosił ją, żeby wysłała mu swoje nagie zdjęcie. Dziewczyna na początku sfrustrowała się i odmówiła nieznajomemu koledze. Paweł nie wycofał się i zaproponował, żeby spotkała się z nim w galerii handlowej. Ania, zakłopotana wcześniejszą propozycją, odmówiła. Wtedy Paweł zagroził, że jeżeli się z nim nie spotka, to któregoś dnia w drodze do szkoły może jej się stać krzywda. Ania bardzo się przestraszyła i od tamtego czasu boi się wychodzić z domu. Zastanawia się, czy nie zrobić sobie nagiego zdjęcia telefonem i wysłać je Pawłowi albo spotkać się z nim osobiście.

Załącznik nr 2. Czynniki chroniące przed groomingiem w portalach społecznościowych

1. Ograniczone zaufanie do profili użytkowników.

2. Unikanie rozmów z dorosłymi.

3. Niepodawanie swoich prawdziwych danych osobowych nieznajomym użytkownikom.

4. Niewysyłanie swoich intymnych zdjęć nieznajomym.

5. Wyłączenie w serwisie społecznościowym funkcji zdradzających naszą rzeczywistą lokalizację.

6. Odrzucanie ofert pracy, propozycji udziału w konkursach, promocjach i podejrzanych wydarzeniach otrzymywanych od nieznajomych.

7. Informowanie rodziców o tym, z kim nawiązujemy nowe znajomości w serwisie społecznościowym.

8. Miejsce na Twoje zasoby:

Gdzie szukać pomocy?

Pedagog/psycholog szkolny: imię i nazwisko (.............................................)

Numer pokoju oraz godziny i dni dyżurów (.............................................

Poradnia psychologiczno-pedagogiczna (adres, telefon, godziny pracy)

Infolinia Dyżurnet: 801615005

Telefon Zaufania dla Dzieci i Młodzieży: 116111

Telefon Zaufania Rzecznika Praw Dziecka: 800121212

Numer alarmowy: 112 


\section{Zakończenie}

Podjęte analizy i interpretacje wskazują na niezwykle dynamiczną aktywność dzieci i młodzieży w cyberprzestrzeni. Aktywność ta ma swoją specyfikę, swój przebieg i wywołuje określone skutki. Niniejsze rozważania jedynie skrótowo pokazują nie w pełni jeszcze zweryfikowany, prakseologiczny wymiar profilaktyki, która ma coraz większe znaczenie zarówno dla rodziny, jak i dla kadry pedagogicznej w szkołach i placówkach opiekuńczo-wychowawczych.

Kiedy w przestrzeni cyfrowej pojawiają się nowe, wyjątkowo niebezpieczne zagrożenia dla najmłodszych użytkowników, wówczas konieczne jest poznanie i stosowanie profilaktyki właśnie o wymiarze prakseologicznym, jej weryfikacja naukowa i przyjmowanie odpowiednich modeli lub procedur postępowania. Należy zwrócić uwagę, że dorobek w zakresie profilaktyki niebezpiecznych zachowań dzieci i młodzieży w rzeczywistości realnej jest bardzo bogaty i obejmuje również zestawy wypracowanych procedur postępowania. Brakuje jednak rozwiązań dotyczących zagrożeń i patologii społecznych występujących w cyberprzestrzeni i światach wirtualnych.

Teoretyczny i empiryczny wymiar zagrożeń cyberprzestrzeni nawiązuje do licznych teorii i koncepcji związanych z aktywnością dzieci i młodzieży w świeci realnym, a także interdyscyplinarnej wiedzy związanej z obszarem nauk społecznych, zwłaszcza pedagogicznych i informatycznych. Należy mieć świadomość niskiego poziomu kwalifikacji i kompetencji rodziców, a także nauczycieli oraz osób zajmujących się profilaktyką w obliczu dynamiki rozwoju cyberprzestrzeni i zagrożeń, jakie ona generuje.

Przedstawiona próba klasyfikacji zagrożeń cyberprzestrzeni wskazuje na synergię, zarówno tradycyjnych zagrożeń świata realnego, jak i nowych, związanych z mediami i technologiami cyfrowymi. W tym ujęciu nowego znaczenia nabierają działania profilaktyczne mające na celu minimalizowanie negatywnych skutków przebywania dzieci i młodzieży online. 
